\title{
STRATEGI PENGEMBANGAN AGRIBISNIS NENAS DI KABUPATEN KUBU RAYA KALIMANTAN BARAT
}

\author{
MELATI FITRI ${ }^{1}$, ERLINDA YURISINTHAE ${ }^{2}$, EVA DOLOROSA $^{2}$ \\ ${ }^{1}$ Alumni Magister Manajemen Agribisnis Fakultas Pertanian \\ Universitas Tanjungpura Pontianak \\ ${ }^{2}$ Staf Pengajar Fakultas Pertanian Universitas Tanjungpura Pontianak
}

\begin{abstract}
This research was conducted in the purpose to understand 1) the internal strategic factors which are the strength and the weakness as well as the external strategic factors which are the opportunity and the threat related to the development of pineapple agribusiness in Kubu Raya Regency, West Kalimantan, 2) to determine the alternative strategy that can be applied for the development of pineapple agribusiness in Kubu Raya Regency, West Kalimantan. This research is a descriptive study. The method used in this research is survey and the correspondents were determined with the purposive sampling method consisting bureaucrats, academics, farmers, and related traders. The result of the research shows that the main strength factor is the availability of a proper pineapples cultivation manual (score: 0.4898). The main weakness factor is unefficient management farmer system (score: 0.2117). The main opportunity factor is the availability of a sustainable development program and the main threat factor is the competitiveness of the product with imported fruits which was still low (score 0.2016). Based on the analysis there are six alternative strategies for the development of pineapples agribusiness in Kubu Raya Regency, West Kalimantan, i.e., 1) the enhancement of pineapple production through training and counseling based on Good Agricultural Practices (GAP) and Standar Operational Procedure (SOP) as well as an expansion of the planting area; 2 ) the enhancement and control of the quality of the product; 3) The enhancement of the production system efficiency; 4) the control of the production from a pest infestation; 5) Developing a partnership pattern and; 6) developing agricultural institutions function.
\end{abstract}

Keywords: Pineapple agribusiness, strategic external factor, strategic internal factor, strategy.

\section{PENDAHULUAN}

Provinsi Kalimantan Barat memiliki peluang untuk dikembangkan sebagai daerah sentra nenas mengingat potensi lahan yang dimiliki masih cukup luas yaitu sekitar 1,6 juta ha lahan gambut yang sangat cocok untuk pengembangan nenas, wilayah sebaran penanaman nenas merata pada setiap kabupaten. Salah satu Kabupaten yang cukup besar luas penanaman nenasnya adalah Kubu Raya.

Kabupaten Kubu Raya adalah Kabupaten baru yang terbentuk berdasarkan Undang-Undang No. 35 Tahun 2007 sebagai pemekaran dari Kabupaten Pontianak. Terletak di bagian Selatan Propinsi Kalimantan Barat merupakan kabupaten pesisir yang penduduknya tersebar pada lokasi yang saling berjauhan. Luas Wilayah Kabupaten Kubu Raya 6.985 Km2 terdiri dari Sembilan (9) 
kecamatan. Berdasarkan data BPS tahun 2010, penduduk Kabupaten Kubu Raya berjumlah 502.249 jiwa yang menempatkannya pada urutan kedua terbesar setelah Kotamadya Pontianak. (BPS Kabupaten Kubu Raya, 2011)

Upaya pembangunan Pertanian di Kabupaten Kubu Raya dilaksanakan secara bertahap dan berkesinambungan. Dinas Pertanian dan Peternakan selaku instansi teknis telah menetapkan Visi dalam upaya pembangunan pertanian yaitu : Terwujudnya Masyarakat Tani Sejahtera, Berwawasan Agribisnis Berbasis Sumber daya Lokal.

Visi ini dijabarkan dalam lima butir misi dimana terdapat tiga butir yang berkaitan erat dengan pengembangan agribisnis komoditi yaitu :

1. Meningkatkan produksi, produktivitas dan mutu hasil tanaman pangan, hortikultura dan peternakan yang aman dan terjangkau oleh masyarakat melalui pemanfaatan sumber daya secara terkendali dan penerapan teknologi yang berwawasan lingkungan.

2. Mengembangkan Pola kemitraan untuk membangun sistim pemasaran dan pengolahan hasil tanaman pangan, hortikultura dan peternakan secara permanen untuk meningkatkan pendapatan petani.

3. Meningkatkan pengelolaan sumber daya lahan, air dan sarana/prasarana pertanian secara optimal, berkelanjutan dan ramah lingkungan guna mendukung produksi pertanian.

\section{Perumusan Masalah}

Dari latar belakang masalah yang telah diuraikan terdahulu maka masalah yang dihadapi dapat dirumuskan sebagai berikut :

1. Faktor-faktor apa saja yang menentukan keberhasilan usaha pengembangan agribisnis nenas di Kabupaten Kubu Raya?

2. Bagaimana alternatif strategi yang dapat dirumuskan untuk mengembangkan agribisnis nenas di Kabupaten Kubu Raya ?

\section{Tujuan Penelitian}

Adapun tujuan dari penelitian ini adalah :

1. Mengetahui dan mengidentifikasi faktor-faktor lingkungan eksternal dan internal yang mempengaruhi usaha pengembangan agribisnis nenas di Kabupaten Kubu Raya.

2. Merumuskan strategi pengembangan agribisnis yang dapat direkomendasikan sebagai bahan pertimbangan dan masukan bagi Pemerintah Kabupaten Kubu Raya untuk menetapkan Strategi dan kebijakan Pengembangan Agribisnis Nenas di Kabupaten Kubu Raya.

\section{METODOLOGI PENELITIAN}

\section{Lokasi dan Waktu Penelitian}

Penelitian dilakukan di Kabupaten Kubu Raya pada 3 kecamatan yaitu : Kecamatan Rasau Jaya, Sungai Raya dan Kubu. Dilakukan secara deskriptif dengan metode survey. Sebagaimana disebutkan oleh Whitney (1960) dalam Nazir (2005) bahwa metode deskriptif adalah pencarian fakta dengan interpretasi yang tepat.

\section{Teknik Pengambilan Sampel}

Teknik pengambilan sampel dengan purposive sampling. Responden terdiri dari 2 (dua) kelompok yaitu dari Para ahli (pakar) yang akan memberikan masukan dalam proses identifikasi dan penentuan faktor-faktor strategis eksternal, 
dan kelompok kedua akan memberikan masukan dalam penentuan faktor strategis internal berjumlah 6 orang, terdiri dari petani nenas , Penyuluh Pertanian Lapangan, Kepala Balai Penyuluhan Pertanian Kecamatan, Ketua Asosiasi Petani nenas Kubu Raya serta Pelaku usaha.

\section{Jenis dan Sumber Data}

Jenis data utama dalam penelitian ini adalah data primer dan data sekunder. Data primer diperoleh langsung dari lapangan melalui daftar pertanyaan (kuesioner), data sekunder diperoleh melalui studi pustaka (literature), dari instansi/lembaga pemerintah ataupun swasta yang dapat memberikan informasi pendukung.

\section{Teknik Pengambilan, Pengolahan dan Analisis Data}

Data dan informasi diolah dan dianalisis secara kualitatif dan kuantitatif. Analisis kuantitatif dilakukan untuk menganalisis lingkungan internal dan eksternal termasuk situasi persaingan yang diwujudkan dalam matriks External Factor Evaluation (EFE) dan matriks Internal Factor Evaluation (IFE). Selanjutnya analisis kualitatif menggunakan matriks SWOT.

\section{Analisis dan Evaluasi Faktor Internal}

Cara untuk melakukan identifikasi terhadap masing-masing faktor lingkungan internal dan faktor lingkungan eksternal adalah dengan menyusun seperangkat item pernyataan pada masing-masing faktor tersebut berdasarkan atas kondisi yang ada, baik kondisi internal maupun eksternal. Berdasarkan hal-hal tersebut dapat disusun pernyataan untuk faktor kekuatan pernyataan untuk faktor kelemahan, peluang dan ancaman.

Penentuan faktor strategis internal dilakukan sebagaimana dapat dilihat pada tabel 1 berikut ini :

Tabel 1. Matrik IFE (Internal Factor Evaluation)

\begin{tabular}{ccc}
\hline $\begin{array}{c}\text { Faktor Penentu } \\
\text { Internal }\end{array}$ & Bobot & Peringkat \\
& & Bobot \\
\hline
\end{tabular}

\section{Kekuatan :}

1.

2.

Kelemahan

1.

2 .

Total 1,0

\section{Analisis dan Evaluasi Faktor Eksternal}

Untuk melakukan analisis dan evaluasi faktor eksternal dilakukan sebagaimana langkah yang dilakukan pada tahap analisis dan evaluasi faktor Internal.

Langkah-langkah yang dilakukan untuk melakukan Evaluasi Faktor Eksternal menurut David (2009) adalah :

- Membuat daftar faktor-faktor eksternal yang diidentifikasi dalam proses audit eksternal. Peluang dituliskan terlebih dahulu kemudian Ancaman.

- Memberikan bobot untuk masing-masing faktor dari 0,0 (tidak penting) sampai 1,0 (sangat penting) . Penjumlahan seluruh bobot harus sama dengan 1,0.

- Memberikan peringkat (rating) untuk masing-masing faktor eksternal tentang seberapa efektif strategi organisasi saat ini dalam memberikan respons faktor-faktor tersebut. Rating $4=$ respons organisasi sangat bagus, $3=$ respons 
organisasi diatas rata-rata, $2=$ respons organisasi rata-rata dan $1=$ respons organisasi dibawah rata-rata.

- Mengalikan bobot setiap faktor dengan peringkatnya untuk menentukan skor bobot.

- Menjumlahkan skor rata-rata untuk setiap variabel guna menentukan skor bobot total untuk organisasi. Skor bobot total tertinggi yang mungkin dicapai oleh sebuah organisasi adalah 4,0 dan skor bobot terendah adalah 1. Rata-rata skor bobot total adalah 2,5. Skor bobot total sebesar 4,0 mengindikasikan bahwa sebuah organisasi merespons secara sangat baik peluang dan ancaman yang ada Untuk lebih jelasnya matrik EFE (External Factor Evaluation) dapat dilihat pada tabel 2 berikut ini :

Tabel 2. Matrik EFE (External Factor Evaluation)

\begin{tabular}{ccc}
\hline $\begin{array}{c}\text { Faktor Penentu } \\
\text { Eksternal }\end{array}$ & Bobot & $\begin{array}{c}\text { Skor } \\
\text { Bobot }\end{array}$ \\
\hline Peluang : & & \\
$1 . \quad \ldots \ldots \ldots \ldots . .$. & & \\
$2 . \quad \ldots \ldots \ldots \ldots . .$. & & \\
Ancaman & & \\
$1 . \quad \ldots \ldots \ldots \ldots . .$. & & \\
$2 . \quad \ldots \ldots \ldots \ldots .$. & 1,0 & \\
\hline Total & & \\
\hline
\end{tabular}

\section{Penyusunan Formulasi Strategi (Matrik SWOT)}

Menurut David (2009), matrik SWOT membantu analisis untuk melakukan perbandingan berpasangan dengan kemungkinan strategi yang dihasilkan berdasarkan pertimbangan kombinasi 4 (empat) set faktor strategi yaitu

a. Strategi SO (Strengths-Oppurtunities) yaitu menggunakan seluruh kekuatan untuk memanfaatkan peluang.

b. Strategi ST (Strengths-Threats) yaitu menggunakan kekuatan yang dimiliki untuk menghindari ancaman

c. Strategi WO (Weakness-Opportunities) yaitu memanfaatkan peluang yang ada dengan cara mengatasi kelemahan-kelemahan yang dimiliki.

d. Strategi WT (Weaknesses-Threats) yaitu kegiatan yang bersifat defensif dan ditujukan untuk meminimalkan kelemahan dan menghindari ancaman.

Hasil Analisis yang dilakukan dituangkan dalam matriks SWOT sebagaimana pada tabel 3 berikut ini :

Tabel 3. Matriks Analisis SWOT

\begin{tabular}{lll}
\hline EFE & KFE & Kelemahan (W) \\
\hline
\end{tabular}

$\begin{array}{lll}\text { Peluang (O) Strategi SO } & \text { Strategi WO }\end{array}$

$\begin{array}{lll}\text { Ancaman (T) } & \text { Strategi ST } & \text { Strategi WT }\end{array}$ 


\section{Identifikasi Faktor Eksternal}

Berdasarkan kuisioner teridentifikasi faktor-faktor eksternal utama sebagai berikut

\section{1) Peluang}

a. Tersedianya Program Pengembangan Berkelanjutan

Program pengembangan hortikultura telah disusun oleh Pemerintah melalui Kementerian Pertanian. Dalam buku Cetak Biru Pengembangan Hortikultura Tahun 2011-2025 (Dirjen Hortikultura, 2012) digambarkan secara rinci program pengembangan hortikultura di Indonesia beserta tahapan pencapaian programnya yang dibagi dalam tiga tahap yaitu : tahap konsolidasi (periode 2011-2015) kenudian tahap percepatan (20162020) sedangkan tahap pemantapan (2021-2025) berisikan tentang pelaksanaan program dan kegiatan yang dapat mempertahankan akselerasi pencapaian sasaran lima tahun sebelumnya.

b. Permintaan Buah Nenas Meningkat

Salah satu indikator meningkatnya permintaan buah nenas adalah terjadinya peningkatan luas panen sebagaimana dicantumkan dalam data statistik tanaman hortikultura yang dikeluarkan oleh kantor BPS Kubu Raya tahun 2011 . Jumlah luas panen dan produksi buah nenas pada tahun 2009 sejumlah 6.955.588 rumpun dengan produksi sebesar 7.714 ton. Pada tahun 2010 terjadi peningkatan luas panen yang cukup besar yaitu : 15.349.614 rumpun dengan produksi mencapai 26.581 ton. Peningkatan luas panen kembali terjadi tahun 2011 dengan jumlah mencapai : 29.423.392 rumpun dengan jumlah produksi 29.842 ton. Angka luas panen dan produksi yang meningkat merupakan salah satu indikator yang dapat menggambarkan bahwa permintaan pasar terhadap produk buah nenas meningkat setiap tahunnya.

c. Tersedianya Industri Pengolahan baik skala Rumah Tangga, industri kecil maupun industri besar berskala ekspor Industri agribisnis nenas memiliki peluang yang cukup baik untuk di kembangkan karena tersedia industri pengolahan nenas baik skala rumah tangga, industri kecil maupun industri besar berskala ekspor.

d. Perkembangan Teknologi Informasi

Perkembangan teknologi informasi yang cepat mendorong berkembangnya pengetahuan dan sikap masyarakat dan petani serta pihak terkait dalam pengembangan agribisnis nenas.

e. Tumbuhnya kesadaran konsumen terhadap produk bermutu dan aman konsumsi.

Kesadaran konsumen terhadap produk bermutu dan aman konsumsi merupakan salah satu peluang dalam pengembangan agribisnis nenas. Peningkatan taraf pendidikan dan pendapatan masyarakat mmempercepat segmentasi pasar. Pengetahuan dan kesadaran tentang dampak residu pestisida dan bahan kimia berbahaya menjadi isu global yang berpengaruh besar terhadap perubahan pola fikir konsumen dalam memilih produk yang akan dikonsumsi. 


\section{2) Ancaman}

a. Persaingan dengan buah-buahan impor

Berdasarkan data dari Direktorat Jenderal Hortikultura, dari tahun 2005 sampai dengan bulan September tahun 2009 terjadi defisit neraca perdagangan hortikultura rata-rata $56,50 \%$ per tahun yaitu dari US\$ 143,71 juta menjadi US\$ -703,91 juta. Dari empat kelompok komoditi hortikultura, komoditi buah yang paling besar neraca defisitnya yaitu dari US\$ -84,01 juta menjadi US\$ -464,02 juta atau meningkat sebesar $68,81 \%$ per tahun.

b. Serangan Organisme Pengganggu Tanaman (OPT)

Terganggunya keseimbangan alam dan pemakaian pestisida yang tidak memperhatikan prinsip Pengelolaan Hama terpadu (PHT) serta akumulasi bahan kimia di alam mengakibatkan terjadinya ledakan hama dan penyakit tertentu serta mutasi yang cepat terhadap OPT yang menyerang tanaman .

c. Tingginya alih fungsi lahan pertanian produktif

Perubahan fungsi lahan ini disebabkan berkembangnya pembangunan pemukiman masyarakat, perkembangan sektor perkebunan yang terus meningkat yang menyebabkan tingginya alih fungsi lahan pertanian produktif.

\section{Identifikasi Faktor Internal}

Berdasarkan kuisioner teridentifikasi faktor-faktor internal utama sebagai berikut

\section{1) Kekuatan}

a. Luas Lahan untuk pengembangan cukup besar

Lahan di daerah Kubu Raya terdiri dari Hutan Negara (355.820 hektar atau 50,88 persen), Perkebunan (67.530 hektar atau 14,81 persen) dan Sawah Pasang Surut (43.710 hektar atau 6,86 persen) yang terhampar diseluruh kecamatan. (BPS Kabupaten Kubu Raya, 2011)

b. Kesesuaian Agroekosistem

Tingginya intensitas cahaya matahari merupakan salah satu kondisi yang sangat mendukung tingginya produksi dan mutu tanaman nenas ini selain factor iklim yang lain.

c. Tersedianya petani dan petugas yang terampil

Dalam upaya meningkatkan kompetensi petani dan petugas telah dilakukan melalui pendidikan dan pelatihan terutama yang berkaitan dengan pengelolaan agribisnis nenas.

d. Dekat dengan pusat pemasaran

Kawasan pengembangan budidaya nenas yang letaknya relatif dekat dengan pusat pemasaran menjadikan pengembangan komoditi ini menjadi menguntungkan terutama kemudahan untuk distribusi ke pasar.

e. Tersedianya panduan budidaya nenas yang baik dan benar (GAP/SOP) Untuk meningkatkan produksi dan mutu komoditi nenas di Kabupaten Kubu Raya dilakukan dengan menerapkan cara pertanian yang baik (GAP), sebagai implementasi lebih lanjut dari GAP telah diterbitkan buku panduan SOP budidaya nenas. SOP budidaya nenas berisikan panduan praktis cara bercocok tanam yang baik dan benar mulai dari tahap penyiapan lahan sampai pada proses panen dan pasca panen. 
Penerapan GAP dan SOP budidaya merupakan langkah yang harus dilakukan untuk memenuhi persyaratan melakukan registrasi kebun, dimana petani dan kelompok tani yang telah melaksanakan prinsip-prinsip GAP dan SOP dengan benar akan diberikan nomer registrasi dan produk yang dihasilkan dari kebun itu akan memiliki mutu dan nilai jual yang terjaga karena akan diberikan label standar mutu produk.

f. Tumbuhnya kelompok penangkar benih nenas

Saat ini di Kabupaten Kubu Raya telah terbentuk kelompok penangkar benih nenas yang dibina oleh petugas yang menangani perbenihan dan sertifikasi.

\section{2) Kelemahan}

a. Manajemen usaha tani masih rendah

Dalam pengembangan agribisnis nenas ini, manajemen usaha tani masih rendah disebabkan oleh perilaku petani yang belum tepat (mulai dari budidaya sampai pemasaran produk). Salah satu adalah kesulitan saat melakukan pencatatan usaha tani .

b. Kualitas (mutu) produk belum terjaga

Kualitas (mutu) produk belum terjaga merupakan kelemahan dalam pengembangan agribisnis nenas. Banyak hal yang menyebabkan kualitas (mutu) produk belum terjaga. Selain diakibatkan serangan Organisme Pengganggu Tanaman (OPT), juga terkait erat dengan pelaksanaan budidaya yang belum sepenuhnya menerapkan panduan SOP, juga disebabkan terbatasnya sarana panen dan pasca panen.

c. Modal petani terbatas

Masalah keterbatasan modal bukan hanya pada sulitnya akses terhadap sumber permodalan melainkan juga pada lemahnya upaya pemupukan modal yang dilakukan oleh petani.

d. Fluktuasi harga yang tinggi

Ketidakseimbangan antara jumlah permintaan dengan pasokan yang tersedia memicu tingginya fluktuasi harga.

e. Akses pasar masih terbatas ke pasar tradisional

Kendala mutu dan kontinyuitas pasokan serta sistim kerjasama yang belum dapat disesuaikan oleh petani menjadi salah satu faktor penyebab rendahnya penyerapan produk nenas di pasar modern.

\section{HASIL DAN PEMBAHASAN}

\section{Analisis dan Evaluasi Internal dan Eksternal}

\section{Evaluasi Faktor Internal}

Setelah faktor kekuatan dan kelemahan yang diperoleh sebagai hasil identifikasi faktor strategis internal selanjutnya dilakukan analisis dengan matriks IFE (internal factor evaluation), dimana setiap faktor diberikan bobot dan rating, maka dapat diperoleh hasil (skor), seperti pada tabel 4 berikut : 
Tabel 4. Analisis Matriks Evaluasi Faktor Internal (IFE)

\begin{tabular}{|c|c|c|c|c|}
\hline Faktor Strategis & Bobot & Peringkat & $\begin{array}{l}\text { Skor } \\
\text { Bobot }\end{array}$ & $\begin{array}{l}\text { Rang- } \\
\text { king }\end{array}$ \\
\hline \multicolumn{5}{|l|}{ Kekuatan } \\
\hline $\begin{array}{l}\text { Luas Lahan untuk pengembangan cukup } \\
\text { besar }\end{array}$ & 0.1173 & 3.8333 & 0.4498 & 2 \\
\hline Kesesuaian Agroekosistem & 0.1122 & 3.6667 & 0.4116 & 3 \\
\hline $\begin{array}{l}\text { Tersedianya petani dan petugas yang } \\
\text { terampil }\end{array}$ & 0.1071 & 3.5000 & 0.3750 & 4 \\
\hline Dekat dengan pusat pemasaran & 0.1020 & 3.3333 & 0.3401 & 5 \\
\hline $\begin{array}{l}\text { Tersedianya panduan budidaya nenas yang } \\
\text { baik dan benar (GAP/SOP) }\end{array}$ & 0.1224 & 4.0000 & 0.4898 & 1 \\
\hline $\begin{array}{l}\text { Tumbuhnya kelompok penangkar benih } \\
\text { nenas }\end{array}$ & 0.1020 & 3.3333 & 0.3401 & 5 \\
\hline Sub Total & 0.6633 & & 2.4065 & \\
\hline \multicolumn{5}{|l|}{ Kelemahan } \\
\hline Manajemen usaha tani masih rendah & 0.0816 & 2.6667 & 0.2117 & 1 \\
\hline Kualitas (mutu) produk belum terjaga & 0.0765 & 2.5000 & 0.1913 & 2 \\
\hline Modal petani terbatas & 0.0714 & 2.3333 & 0.1667 & 3 \\
\hline Fluktuasi harga yang tinggi & 0.0663 & 2.1667 & 0.1437 & 4 \\
\hline $\begin{array}{l}\text { Akses pasar masih terbatas ke pasar } \\
\text { tradisional }\end{array}$ & 0.0408 & 1.3333 & 0.0544 & 5 \\
\hline Sub Total & 0.3367 & & 0.7738 & \\
\hline Total & 1.0000 & & 3.1803 & \\
\hline
\end{tabular}

Sumber : Analisa Hasil Perhitungan (2013)

Bedasarkan hasil perhitungan diatas, secara prioritas faktor kekuatan yang mempengaruhi perkembangan agribisnis nenas di Kabupaten Kubu Raya. Adapun faktor yang paling mempengaruhinya adalah Tersedianya panduan budidaya nenas yang baik dan benar (GAP/SOP) (nilai 0,4498).

Faktor strategis kekuatan yang memiliki skor bobot terkecil adalah : dekat dengan pusat pemasaran dan tumbuhnya kelompok penangkar benih nenas dengan skor bobot 0.3401 .

Faktor kelemahan utama dalam pengembangan agribisnis nenas ini adalah manajemen usaha tani masih rendah $(0.2177)$. Hal ini berkaitan erat dengan tingkat pendidikan petani yang umumnya masih rendah.

Dari tabel 4 dapat dilihat bahwa skor bobot faktor kekuatan internal (2.4065) lebih besar dari skor bobot kelemahan internal (0.7738) . Hal ini menunjukkan bahwa pengembangan agribisnis nenas memiliki kekuatan internal yang lebih besar dan dapat meminimalkan kelemahan yang ada.

\section{Evaluasi Faktor Eksternal}

Faktor peluang dan ancaman dalam pengembangan agribisnis nenas selanjutnya diidentifikasi dan dianalisis lalu dimasukkan ke dalam matriks Evaluasi Faktor Eksternal (EFE) seperti yang tercantum pada tabel 5 berikut ini : 
Tabel 5. Analisis Matriks Evaluasi Faktor Eksternal (EFE)

\begin{tabular}{|c|c|c|c|c|}
\hline Faktor Strategis & Bobot & Peringkat & $\begin{array}{l}\text { Skor } \\
\text { Bobot }\end{array}$ & $\begin{array}{l}\text { Rang- } \\
\text { king }\end{array}$ \\
\hline Peluang & & & & \\
\hline $\begin{array}{l}\text { Tersedianya Program Pengembangan } \\
\text { Berkelanjutan }\end{array}$ & 0.1481 & 4.0000 & 0.5926 & 1 \\
\hline Permintaan Buah Nenas Meningkat & 0.1420 & 3.8333 & 0.5442 & 2 \\
\hline $\begin{array}{l}\text { Tersedianya Industri Pengolahan baik skala } \\
\text { Rumah Tangga, industri kecil maupun } \\
\text { industri besar berskala ekspor }\end{array}$ & 0.1358 & 3.6667 & 0.4979 & 3 \\
\hline Perkembangan Teknologi Informasi & 0.1235 & 3.3333 & 0.4115 & 5 \\
\hline $\begin{array}{l}\text { Tumbuhnya kesadaran konsumen terhadap } \\
\text { produk bermutu dan aman konsumsi }\end{array}$ & 0.1296 & 3.5000 & 0.4537 & 4 \\
\hline $\begin{array}{l}\text { Sub Total } \\
\text { Ancaman }\end{array}$ & 0.6790 & & 2.5000 & \\
\hline Persaingan dengan buah-buahan impor & 0.0864 & 2.3333 & 0.2016 & 1 \\
\hline $\begin{array}{l}\text { Serangan Organisme Pengganggu Tanaman } \\
\text { (OPT) }\end{array}$ & 0.0802 & 2.1667 & 0.1739 & 2 \\
\hline $\begin{array}{l}\text { Tingginya alih fungsi lahan pertanian } \\
\text { produktif }\end{array}$ & 0.0556 & 1.5000 & 0.0833 & 3 \\
\hline $\begin{array}{l}\text { Pengembangan komoditi lain yang dianggap } \\
\text { lebih kompetitif }\end{array}$ & 0.0494 & 1.3333 & 0.0658 & 4 \\
\hline Suku Bunga dan Biaya Bank tinggi & 0.0494 & 1.3333 & 0.0658 & 4 \\
\hline Sub Total & 0.3210 & & 0,5905 & \\
\hline Total & 1.0000 & & 3.0905 & \\
\hline
\end{tabular}

Sumber : Analisa Hasil Perhitungan (2013)

Bedasarkan hasil perhitungan diatas, faktor peluang dengan skor bobot tertinggi adalah tersedianya program pengembangan berkelanjutan dengan skor bobot (0.5926)

Faktor ancaman terbesar dalam usaha budidaya agribisnis nenas di Kabupaten Kubu Raya adalah persaingan dengan buah-buah impor $(0,2016)$.

Dari tabel 5 dapat dilihat bahwa nilai total skor bobot untuk faktor strategis eksternal peluang adalah (2.5000) lebih besar dari skor bobot faktor ancaman sebesar (0.5905), hal ini menunjukkan bahwa usaha agribisnis nenas di Kabupaten Kubu Raya memiliki faktor peluang yang lebih besar dan faktor kelemahannya dapat diminimalisir.

\section{Analisis SWOT}

Nilai matrik Evaluasi Faktor Internal (IFE), kekuatan internal $(2,4065)$ lebih besar dari kelemahan internal (0,7738). Nilai matrik Evaluasi Faktor Eksternal (EFE), peluang eksternal $(2,5000)$ lebih besar dari ancaman eksternal $(0,5905)$. Dari data tersebut dapat diketahui dalam pengembangan agribisnis nenas di Kabupaten Kubu Raya memiliki faktor kekuatan internal dan faktor peluang eksternal yang sangat besar sehingga dapat memanfaatkan peluang yang ada. Berdasarkan kondisi tersebut diagram analisis SWOT berada pada posisi kuadran 1 (satu), dimana strategi yang dapat diterapkan yaitu mendukung kebijakan pertumbuhan yang agresif (growth oriented strategy). Untuk lebih jelasnya posisi usaha agribisnis nenas berdasarkan analisis SWOT dapat dilihat pada gambar 1 berikut ini : 


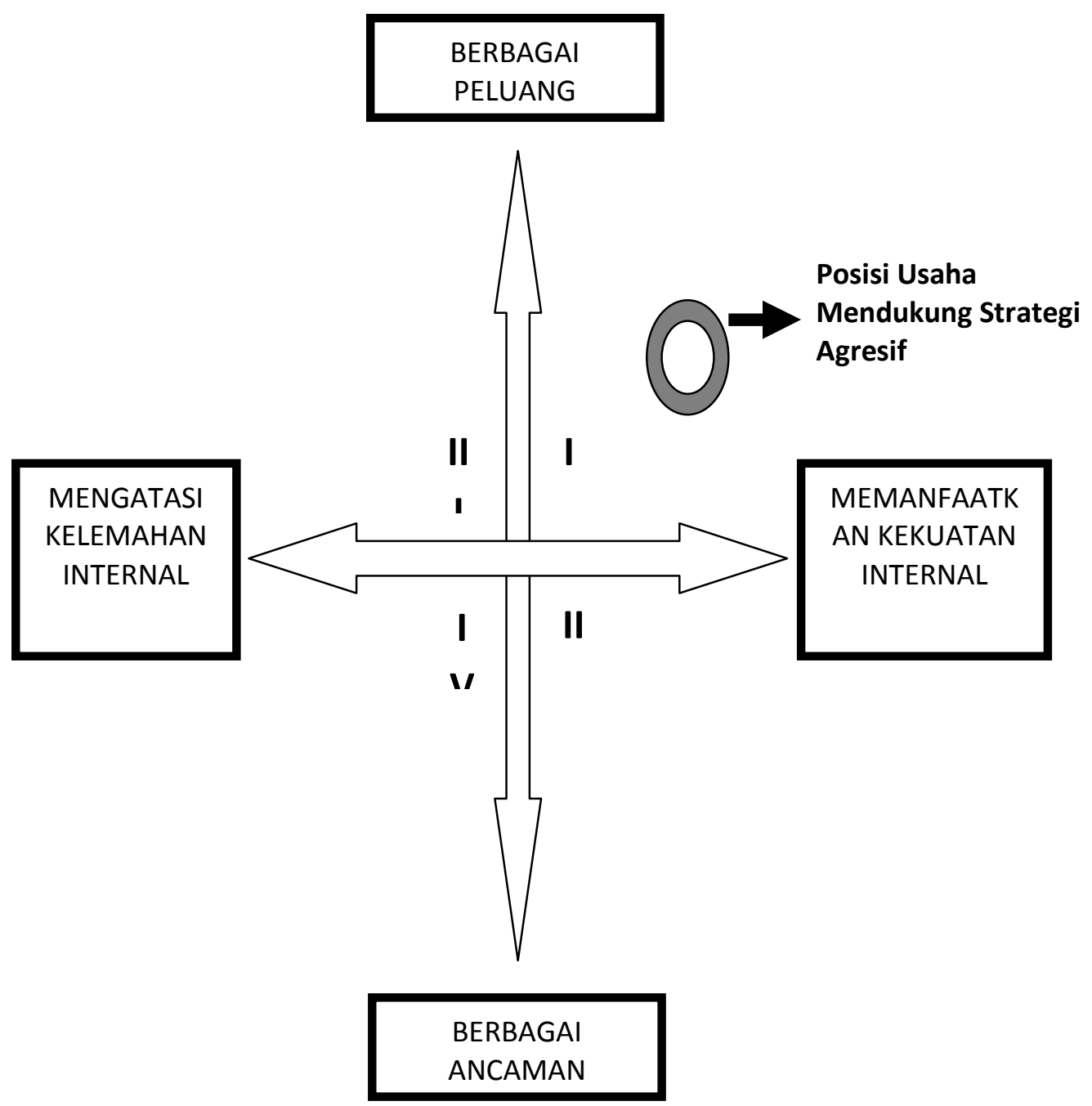

Gambar 1. Analisis SWOT

\section{Alternatif Strategi Pengembangan Agribisnis}

Berdasarkan analisis matrik SWOT tersebut dapat di susun 4 (empat) strategi utama yaitu : strategi Strengths- Opportunuties (SO), strategi Weaknesses - Opportunuties (WO), strategi Strengths - Threats (ST) dan strategi Weaknesses - Threats $(W T)$. Secara detail strategi tersebut dapat dilihat pada Tabel 6, dimana masing- masing strategi ini memiliki karakteristik sendiri, namun dalam implementasi strategi dapat dilaksanakan secara bersama-sama dan saling mendukung satu sama lainnya. 
Tabel 6. Penentuan Strategi Berdasarkan Matrik SWOT

\begin{tabular}{|c|c|c|}
\hline EKSTERNAL & \begin{tabular}{ll}
\multicolumn{2}{l}{ Kekuatan (Strength) } \\
1. Luas Lahan untuk \\
pengembangan cukup \\
besar \\
2. Kesesuaian \\
Agroekosistem \\
3. Tersedianya petani \\
dan petugas yang \\
terampil \\
4. Dekat dengan pusat \\
pemasaran \\
5. Tersedianya panduan \\
budidaya nenas yang \\
baik dan benar \\
(GAP/SOP) \\
6. Tumbuhnya \\
kelompok penangkar \\
benih nenas
\end{tabular} & $\begin{array}{l}\text { Kelemahan (Weakness) } \\
\text { 1. Manajemen usaha } \\
\text { tani masih rendah } \\
\text { 2. Kualitas (mutu) } \\
\text { produk belum } \\
\text { terjaga } \\
\text { 3. Modal petani } \\
\text { terbatas } \\
\text { 4. Fluktuasi harga } \\
\text { yang tinggi } \\
\text { 5. Akses pasar masih } \\
\text { terbatas ke pasar } \\
\text { tradisional }\end{array}$ \\
\hline $\begin{array}{ll}\text { Peluang (Oppurtunity) } \\
\text { 1. Tersedianya Program } \\
\text { Pengembangan } \\
\text { Berkelanjutan } \\
\text { 2. Permintaan Buah Nenas } \\
\text { Meningkat } \\
\text { 3. Tersedianya Industri } \\
\text { Pengolahan baik skala } \\
\text { Rumah Tangga, industri } \\
\text { kecil maupun industri besar } \\
\text { berskala ekspor } \\
\text { 4. Perkembangan Teknologi } \\
\text { Informasi } \\
\text { 5. Tumbuhnya kesadaran } \\
\text { konsumen terhadap produk } \\
\text { bermutu dan aman } \\
\text { konsumsi }\end{array}$ & $\begin{array}{ll}\text { Strategi S-O } \\
\text { 1. } & \text { Mengembangkan } \\
& \text { kawasan budidaya } \\
& \text { nenas berkelanjutan } \\
& \text { (S1,S2,S4,O1,O2,O3) } \\
\text { 2. } & \text { Menerapkan sistim } \\
& \text { jaminan mutu produk } \\
\text { segar dan olahan } \\
\text { (S4,S5,O2,O3,O5) } \\
\text { 3. } & \text { Meningkatkan } \\
\text { kapasitas sumberdaya } \\
\text { manusia dan } \\
\text { kelembagaan dengan } \\
\text { pendidikan dan } \\
\text { pelatihan } \\
\text { (S3,S5,S6,O4,O5) }\end{array}$ & $\begin{array}{ll}\text { Strategi W-O } \\
\text { 1. } \\
\text { Membina petani dan } \\
\text { pelaku usaha } \\
\text { melalui penyuluhan } \\
\text { dalam pengelolaan } \\
\text { usaha taninya } \\
\text { (W1,W2,O1,O4) } \\
\text { 2. Memfasilitasi } \\
\text { pembentukan dan } \\
\text { pengembangan pola } \\
\text { kemitraan } \\
\text { (W2,W3,W5,O1,O2 } \\
\text {,O3) } \\
\text { 3enyediakan data } \\
\text { dan informasi yang } \\
\text { mutakhir, mudah } \\
\text { dan cepat diakses } \\
\text { (W4,W5,O3,O4,O5) }\end{array}$ \\
\hline $\begin{array}{l}\text { Ancaman (Threat) } \\
\text { 1. Persaingan dengan buah- } \\
\text { buahan impor } \\
\text { 2. Serangan Organisme } \\
\text { Pengganggu Tanaman } \\
\text { (OPT) } \\
\text { 3. Tingginya alih fungsi lahan } \\
\text { pertanian produktif } \\
\text { 4. Pengembangan komoditi } \\
\text { lain yang dianggap lebih } \\
\text { kompetitif } \\
\text { 5. Suku Bunga dan Biaya } \\
\text { Bank tinggi }\end{array}$ & 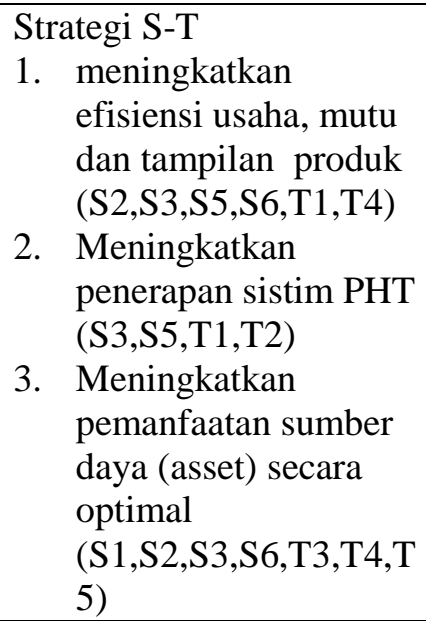 & \begin{tabular}{ll} 
Strategi W-T \\
1. & Menyediakan \\
& fasilitas pendukung \\
pada lokasi & \multicolumn{1}{c}{ longan } \\
pengembangan \\
(W4,T1,T3,T4) \\
2. & $\begin{array}{l}\text { Mengembangkan } \\
\text { kemandirian petani }\end{array}$ \\
& (W1,W2,W3,T1,T5) \\
3. & $\begin{array}{l}\text { Diversifikasi usaha } \\
\text { (W1,W3,T3,T4) }\end{array}$
\end{tabular} \\
\hline
\end{tabular}


Berdasarkan matrik SWOT tersebut didapat beberapa alternatif formulasi strategi yang dapat direkomendasikan dan perlu diantisipasi dalam rangka upaya pencapaian keberhasilan pengembagan agribisnis nenas di kabupaten Kubu Raya. Adapun strategi dimaksud adalah :

\section{Strategi Strengths - Opportunities (SO)}

Strategi ini menggunakan seluruh faktor kekuatan yang dimiliki untuk menfaatkan peluang yang ada. Analisis yang dilakukan menghasilkan beberapa strategi berikut :

a. Mengembangkan kawasan budidaya nenas berkelanjutan

Strategi ini merupakan upaya mempertahankan lahan- lahan yang dianggap potensial dan secara fungsional dapat dijadikan lahan penanaman nenas, dilakukan dengan menginventarisasi dan melakukan pemetaan dan penyajian informasi tentang kemampuan daya dukung lahan untuk pertanaman nenas yang ditindaklanjuti dengan upaya menyusun regulasi mendukung perlindungan lahan budidaya nenas di Kabupaten Kubu Raya.

b. Menerapkan sistim jaminan mutu produk segar dan olahan

Mutu produk untuk komoditi buah segar dan olahan dapat dijaga melalui penerapan norma yang menjadi persyaratan utama untuk mendapatkan sertifikasi jaminan mutu.

c. Meningkatkan kapasitas sumber daya manusia dan kelembagaan dapat dilakukan melalui kegiatan- kegiatan sebagai berikut :

$>$ Mengintensifkan program penyuluhan

$>$ Meningkatkan kapasitas petugas melalui pelatihan-pelatihan khususnya terhadap petugas lapangan ( PPL) dan kelompokkelompok tani.

Melaksanakan sistem kerja yang efektif.

\section{Strategi Strengths -Threats (ST)}

Strategi ini menggunakan seluruh faktor kekuatan yang dimiliki dengan cara menghindari atau mengatasi ancaman. Analisis yang dilakukan menghasilkan beberapa strategi berikut ini :

a. Meningkatkan efisiensi usaha tani, mutu dan tampilan produk

Secara spesifik standar kualitas nenas dilakukan dengan melakukan pemilihan dan pengelompokan berdasarkan kondisi dan tampilan buah.

b. Meningkatkan penerapan sistem perlindungan hama terpadu Upaya tersebut dapat dilaksanakan melalui penerapan sistem pengendalian perlindungan tanaman yang dapat menunjang pengamanan produksi.

c. Pemanfaatan sumber daya (asset) secara optimal

Sumber daya asset saat ini yang ada baik berupa lahan, tenaga kerja, fasilitas terutama gudang-gudang swasta atau KUD, sarana dan prasarana pemerintahan/umum lainnya dapat dimanfaatkan secara optimal.

\section{Strategi Weakneesses - Oppurtunities (WO)}

Strategi ini diterapkan berdasarkan pemanfaatan peluang yang ada dengan cara meminimalkan faktor kelemahan yang dimiliki. Analisis yang dilakukan menghasilkan beberapa strategi sebagai berikut : 
a. Membina petani dan pelaku usaha dengan penyuluhan dan pendampingan dalam pengelolaan usaha tani.

dapat dilakukan dengan inkubator agribisnis, sekolah lapang dan penyuluhan yang efektif dengan disertai peranan aparat/ penyuluh.

b. Memfasilitasi pembentukan dan pengembangan pola kemitraan

Dengan strategi ini diharapkan petani mempunyai akses kelembagaan keuangan untuk membantu permodalan, peningkatan keterampilan, kewirausahaan, adopsi teknologi, informasi, pemasaran dan pembagian resiko yang adil.

c. Menyediakan data dan informasi yang mutakhir, mudah dan cepat diakses.

Pelayanan informasi dapat dilakukan terhadap hal- hal seperti peluang pasar, harga, standar kualitas, teknologi, sistem perdagangan, mitra usaha dan informasi lainnya yang diperlukan para pelaku agribisnis.

\section{Strategi Weaknesses - Threats (WT)}

Strategi ini didasarkan pada kegiatan yang berusaha meminimalkan kelemahan yang dimiliki serta menghindari ancaman yang ada. Analisis yang dilakukan menghasilkan beberapa strategi berikut ini :

a. Menyediakan fasilitas pendukung pada lokasi pengembangan.

Strategi ini dapat dilakukan oleh pemerintah daerah khususnya, guna membantu mengatasi keterbatasan dari para pelaku agribisnis nenas.

b. Mengembangkan kemandirian petani

Dapat dilakukan melalui kegiatan - kegiatan pelatihan kepada kelompok tani, magang atau mengikuti studi banding, dukungan fasilitas, sarana dan prasarana.

c. Diversifikasi usaha.

Untuk mengantisipasi membanjirnya produk dan rendahnya harga jual dapat dilakukan dengan mengusahakan industri pengelohan buah secara sederhana, baik berupa sirup (juice) atau produk olahan lainnya.

\section{Program Pengembangan}

Beberapa program dan kegiatan pengembangan agribisnis nenas di kabupaten Kubu Raya dapat direkomendasikan sebagai berikut :

1. Program peningkatan produksi, produktivitas dan mutu buah nenas

a. Dapat dilakukan dengan melaksanakan penerapan teknik bercocok tanam yang baik (Good Agricultural Practices/GAP) dan sesuai dengan panduan teknis budidaya yang telah ditentukan dalam Standar Operasional Procedure (SOP). Peningkatan produksi ini dicapai melalui perbaikan mutu bibit, pola penanaman dengan penambahan jumlah populasi per hektar, pengaturan produksi buah melalui perangsangan pembuahan (forcing), pengendalian Organisme Pengganggu Tanaman (OPT) yang sesuai dengan prinsip Pengendalian Hama Terpadu (PHT), serta penanganan panen dan pasca panen yang tepat,

b. Perluasan areal pertanaman memenuhi skala ekonomi yang layak di tingkat usaha tani dan wilayah.

c. Penerapan sistim jaminan mutu melalui penetapan dan pengembangan registrasi kebun buah pada petani dan kelompok tani serta kelompok pengolahan hasil hortikultura. 


\section{Program peningkatan kapasitas sumberdaya manusia}

a. Peningkatan pembinaan dan penyuluhan untuk mendorong partisipasi petani agar mampu berperan secara optimal dalam pengembangan usaha agribisnisnya.

b. Meningkatkan kualitas dan kuantitas pendidikan dan pelatihan terhadap petugas (PPL) dan kelompok tani.

c. Percepatan implementasi teknik budidaya yang baik melalui sekolah lapang GAP/SOP dan sekolah lapang pengendalian hama terpadu, magang dan penambahan wawasan melalui studi banding.

\section{Program penataan pemasaran}

a. Peningkatan pelayanan informasi pasar, yang meliputi peluang pasar, harga, standar kualitas, sistem perdagangan dan sebagainya melalui jaringan informasi secara terbuka dan diseminasikan kepada seluruh para pelaku agribisnis.

b. Penataan rantai pasokan melalui pengembangan sistim manajemen untuk perbaikan penyaluran produk, informasi, pelayanan dan dari produsen ke pengguna akhir (konsumen).

\section{Program pengembangan kemitraan}

a. Menciptakan terwujudnya kerjasama kemitraan antara pelaku usaha hortikultura mikro, kecil, menengah dan besar. Pola kemitraan dapat berbentuk kontrak budidaya, bagi hasil dan kerjasama operasional.

b. Meningkatkan efektifitas pelaksanaan pola kemitraan yang telah berjalan selama ini dan melakukan evaluasi untuk mengatasi kelemahan dan kekurangan dalam pelaksanaannya.

\section{Program pengembangan sarana dan prasarana}

a. Pembangunan infrastruktur jaringan transportasi, jalan usaha tani dan irigasi. Pemerintah membangun dan memelihara prasarana yang tidak mampu dibangun oleh petani.

b. Penyediaan alat dan mesin pertanian, pembangunan packing house, alat dan mesin panen dan pasca panen serta fasilitasi sarana transportasi baik berupa jalan maupun pelabuhan sungai/laut.

c. Penyediaan fasilitas kredit program dengan bunga yang terjangkau, guna mendukung investasi dan permodalan petani.

d. Peningkatan dukungan berupa bantuan sarana produksi, teknologi dan distribusi.

\section{Program Pengembangan Kelembagaan}

a. Peningkatan kualitas sumber daya manusia pelaku kelembagaan baik yang berada dalam kelompok tani, asosiasi, pemasaran dan lain-lain melalui pendidikan dan pelatihan.

b. Penguatan peran koperasi, asosiasi dan meningkatkan peranan lembaga penyuluhan, perbankan sehingga lebih mudah diakses oleh petani.

c. Peningkatan peran lembaga penelitian dan pengembangan yang dapat memberikan alternative penerapan teknologi terbaru kepada petani dan pelaku usaha lainnya.

d. Peningkatan kemandirian petani yang tergabung didalam kelompok tani melalui pembinaan intensif dan berkelanjutan sehingga petani dapat berperan sebagai subjek pelaksana pembangunan. 


\section{KESIMPULAN}

1. Kondisi usaha tani nenas di Kabupaten Kubu Raya saat ini memiliki kekuatan dan peluang yang sangat besar tetapi masih diperlukan upaya pengembangan yang tepat melalui pelaksanaan program dan kegiatan yang dapat mempercepat pencapaian sasaran peningkatan produksi, produktivitas dan mutu yang akan berdampak pada peningkatan pendapatan petani.

2. Faktor Lingkungan eksternal dan internal yang paling berpengaruh dalam pengembangan agribisnis nenas di Kabupaten Kubu Raya adalah faktor eksternal peluang dan faktor internal kekuatan.

3. Berdasarkan hasil analisis, faktor eksternal yang berpengaruh dalam pengembangan agribisnis nenas di Kabupaten Kubu Raya adalah : Faktor Peluang berdasarkan urutan rangking : 1) Tersedianya program pengembangan berkelanjutan ; 2) Permintaan buah nenas meningkat ; 3) Tersedianya industri Pengolahan baik skala rumah tangga, industry kecil maupun industry besar berskala ekspor ; 4) Tumbuhnya kesadaran konsumen terhadap produk bermutu dan aman konsumsi dan 5) Perkembangan Teknologi informasi . Adapun Ancaman yang dihadapi berdasarkan urutan rangking adalah : 1) Persaingan dengan buah-buahan impor; 2) Serangan Organisme Pengganggu Tanaman ;3) Tingginya alih fungsi lahan pertanian produktif ; 4) Pengembangan komoditi lain yang dianggap lebih kompetitif dan 5) Suku bunga dan biaya bank tinggi .

4. Faktor internal yang berpengaruh dalam pengembangan agribisnis nenas di Kabupaten Kubu Raya adalah Faktor Kekuatan berdasarkan urutan rangking : 1) Tersedianya panduan budidaya nenas yang baik dan benar

; 2) Luas lahan untuk pengembangan cukup besar ; 3) Kesesuaian agroekosistem ; 4) Tersedianya petani dan petugas yang terampil ; dan 5) Dekat dengan pusat pemasaran . Adapun Faktor Kelemahan berdasarkan urutan rangking adalah : 1) Manajemen usaha tani masih rendah ; 2) Kualitas (mutu) produk belum terjaga ; 3) Modal petani terbatas ; 4) Fluktuasi harga yang tinggi (dan 5kses pasar masih terbatas ke pasar tradisional .

5. Berdasarkan hasil analisis SWOT (strengths, weaknesses, opportunities, treats) terhadap faktor-faktor lingkungan eksternal dan internal berada pada posisi kuadran 1 (satu), dimana strategi yang dapat diterapkan yaitu mendukung kebijakan pertumbuhan yang agresif (growth oriented strategy).

6. Adapun pilihan strategi dalam pengembangan agribisnis nenas adalah :

(1) Peningkatan produksi nenas dengan pembinaan dan penyuluhan sesuai GAP/SOP serta perluasan areal tanam,

(2) Peningkatan kualitas produk dan menjaga mutu buah

(3) Meningkatkan efisiensi sistem produksi

4) Pengamanan produksi dari serangan OPT,

5) Pengembangan pola kemitraan dan

6) Mengembangkan fungsi kelembagaan pertanian.

7. Program yang direkomendasikan untuk dilaksanakan oleh Pemerintah Kabupaten Kubu Raya dalam pengembangan agribisnis nenas adalah :

1) Program peningkatan produksi, produktivitas dan mutu buah nenas 
2) Program pengembangan sumber daya manusia

3) Program peningkatan pemasaran

4) Program pengembangan kemitraan

5) Program pengembangan sarana dan prasarana.

\section{SARAN}

1. Untuk mendorong percepatan pelaksanaan pengembangan agribisnis nenas, perlu diciptakan dan dikembangkan pola kemitraan antara petani dengan pengusaha,/koperasi serta pembinaan terhadap asosiasi yang telah terbentuk agar tercipta sinergi yang saling menguntungkan. Oleh sebab itu pemerintah Daerah perlu menciptakan iklim usaha yang kondusif dan dapat menjamin kelancaran usaha kemitraan tersebut.

2. Pemerintah Kabupaten Kubu Raya diharapkan segera dapat membentuk zonasi kawasan budidaya dan membuat kebijakan serta peraturakan yang jelas untuk melindungi kawasan budidaya pertanian dari ancaman alih fungsi lahan baik oleh pengembangan komoditi perkebunan (sawit) maupun peruntukan lainnya (perumahan, dll).

3. Dipandang perlu untuk dilakukan penelitian lebih lanjut sehingga dapat menentukan pilihan strategi yang paling efektif untuk diterapkan di Kabupaten Kubu Raya.

\section{DAFTAR PUSTAKA}

David, F.R. 2009. Manajemen Strategis (Konsep). Edisi 12. Salemba Empat. Jakarta.

Badan Pusat Statistik. 2011. Kabupaten Kubu Raya Dalam Angka. Tahun 2011. Katalog BPS : 1102001.611. Kubu Raya, Kalimantan Barat.

Kementerian Pertanian. 2012. Cetak Biru Pengembangan Hortikultura Tahun 2011- 2025. Direktorat Jenderal Hortikultura. Jakarta.

Nazir. M. 2009. Metode Penelitian. Ghalia Indonesia. Jakarta.

Pemerintah Kabupaten Kubu Raya. 2009 Laporan Tahunan Dinas Pertanian dan Peternakan Kabupaten Kubu Raya. Dinas Pertanian dan Peternakan Kabupaten Kubu Raya

Pemerintah Provinsi Kalimantan Barat. 2008. Standar Operasional Prosedur (SOP) Nenas Smooth Cayenne Kabupaten Kubu Raya Propinsi KalBar.Dinas Pertanian Tanaman Pangan dan Hortikultura Prov. Kal-Bar. 